\title{
Kötődési stílus, kapcsolati és szexuális elégedettség: emlőrákos és egészséges nők összehasonlító vizsgálata
}

\author{
Désfalvi Judit $^{1,2}$ - Lakatos Csilla ${ }^{2}$ - Csuka Sára Imola ${ }^{2}$. Sallay Viola dr. ${ }^{3}$ \\ Filep Orsolya ${ }^{2}$ - Dank Magdolna dr. ${ }^{1}$ - Martos Tamás dr. ${ }^{3}$ \\ ${ }^{1}$ Semmelweis Egyetem, Általános Orvostudományi Kar, Onkológiai Központ, Budapest \\ ${ }^{2}$ Semmelweis Egyetem, Rácz Károly Doktori Iskola, Budapest \\ ${ }^{3}$ Szegedi Tudományegyetem, Általános Orvostudományi Kar, Pszichológiai Intézet, Szeged
}

Bevezetés: Számos tanulmány vizsgálta az emlőrákkal diagnosztizált nők kötődési stílusát, és az eddigi eredmények rámutatnak arra, hogy a betegek életminőségének és a gyógyulás optimális feltételeinek biztosítása érdekében fontos figyelembe venni a kötődési mintázat és a kapcsolati jellemzők közötti összefüggéseket is.

Célkitüzés és módszer: A jelen tanulmányban emlőrákkal diagnosztizált nők kötődési stílusát $(\mathrm{n}=135)$ kívánjuk felmérni, és összehasonlítani emlőrákkal nem diagnosztizált nők csoportjával ( $\mathrm{n}=137)$ a felnőttkori kötődés, szorongás és elkerülés dimenziói mentén. Vizsgáljuk továbbá a felnőttkori kötődés jellemzőinek összefüggéseit a szubjektív egészségi állapottal, valamint a párkapcsolattal és a szexuális kapcsolattal való elégedettség között.

Eredmények: A diagnosztizált csoportra a kötődési mintázat szempontjából magasabb elkerülés, továbbá rosszabb szubjektív egészségi állapot, alacsonyabb kapcsolati és szexuális elégedettség volt jellemző. A magasabb elkerülés és a magasabb szorongás is alacsonyabb kapcsolati elégedettséget jelzett előre, míg a szexuális elégedettség az emlőrák diagnózisával mutatott negatív, a szubjektív egészségi állapottal pedig pozitív összefüggést.

Következtetés: Eredményeink arra utalnak, hogy az emlőrákkal diagnosztizált nők kötődési mintázata, emellett pedig szubjektív egészségi állapota is szerepet játszhat párkapcsolati és szexuális elégedettségükben. A páciensek testi, lelki és kapcsolati jellemzőinek figyelemmel kísérése és támogatása hozzájárulhat a jobb életminőség eléréséhez.

Orv Hetil. 2020; 161(13): 510-518.

Kulcsszavak: emlőrák, felnőttkori kötődés, kapcsolati elégedettség, szexuális elégedettség

\section{Attachment style, relationship and sexual satisfaction: comparing breast cancer patients and healthy women}

Introduction: Many studies have investigated attachment styles in adults diagnosed with breast cancer: previous results indicate the importance of considering the associations between attachment style and relationship functioning in order to support better quality of life and optimal healing process in patients.

Aim and method: In this study we intend to assess the attachment style (anxiety and avoidance) of Hungarian women diagnosed with breast cancer $(\mathrm{n}=135)$ and to compare it with a group of women not diagnosed with cancer $(\mathrm{n}=137)$. We examined attachment style in relation to self-rated health as well as relational and sexual satisfaction. Results: In the diagnosed group, we found higher level of avoidant attachment as well as poorer self-rated health, and lower relationship and sexual satisfaction. Both higher avoidance and anxiety predicted lower relationship satisfaction, while sexual satisfaction was predicted by having a breast cancer diagnosis and better self-rated health.

Conclusion: Our results indicate that the attachment pattern of women diagnosed with cancer can play a role in their relationships and sexual satisfaction, along with their subjective health status. Monitoring and supporting physical, mental and relational characteristics may contribute to the attainment of better quality of life.

Keywords: breast cancer, adult attachment, relationship satisfaction, sexual satisfaction

Désfalvi J, Lakatos Cs, Csuka SI, Sallay V, Filep O, Dank M, Martos T. [Attachment style, relationship and sexual satisfaction: comparing breast cancer patients and healthy women]. Orv Hetil. 2020; 161(13): 510-518.

(Beérkezett: 2019. november 12.; elfogadva: 2019. december 31.) 


\section{Rövidítés}

RSQ = (Relationship Scales Questionnaire $)$ Kapcsolati Kérdőív (a felnőttkori kötődés mérése)

A rosszindulatú daganattal diagnosztizált betegek pszichés múködésével foglalkozó tanulmányok közül több is megállapította a társas támogatottság fontosságát: az alacsony szintű támogatással olyan mentális problémák járnak együtt, mint a szorongás, a depresszió, valamint a betegséggel, illetve a személyes kapcsolatokkal, környezettel szembeni bizonytalanságok és félelmek [1-4]. Számos eredmény bizonyította, hogy a társkapcsolattal való elégedettség pozitívan hat a betegség és a kezelések tüneteinek jobb elviselésére, valamint csökkentheti a szorongás, depresszió és a halálozás kockázatát [5]. Kevés olyan munka született azonban, amely az emlőrákkal küzdők társkapcsolati elégedettségét a kötődési dimenziók (például szorongó, bizonytalan) mentén vizsgálná, és az eredményeket egészséges nőtársaik eredményével összevetné. A jelen tanulmányban emlőrákkal diagnosztizált nők (a továbbiakban: diagnosztizált) kötődési stílusát kívánjuk felmérni társkapcsolati és szexuális elégedettségük viszonylatában, és egy daganatos betegséggel nem diagnosztizált (továbbiakban: egészséges), korban, életviteli státuszban hasonló női csoporttal kívánjuk őket összehasonlítani. Jelen munkánkkal igyekszünk a kötődési dimenziók olyan összefüggéseit, kapcsolatait feltárni, amelyekről eddig nem találtunk információt az ismert szakirodalmakból.

A rák diagnózisa a legtöbbször nagymérvű félelemmel, kilátástalansággal, a bizonytalanság érzésével sújt a betegre. Egy emlőrákos nő nem csupán az élet végességével való szembesüléstől, hanem testének negatív változásaitól, nőiessége elveszítésétől, kapcsolatainak megszakadásától, az elhagyatástól, a magánytól fél a leginkább [6].

A korai esetben a betegség prognózisa a legtöbbször kedvező, gyógyítható. A stádiumok tekintetében az I. stádium esetében a betegség csak az emlőben található, nem terjed a környező nyirokcsomókba, és nem ad távoli szervbe áttétet. Szorongást okoz az, hogy a mútétet követően a tumormentes betegnek úgynevezett adjuváns terápiát adnak, amikor a keringésben lévő daganatsejteket, az úgynevezett mikroáttéteket pusztítják [7]. Nehéz megérteni, hogy miért van szükség ilyenkor kezelésre. Amikor távoli szervekben áttét alakul ki, akkor még mindig két csoportba oszthatjuk a pácienseket. Van, akinél semmilyen tünet vagy panasz nem jelentkezik, míg más betegeknél föllépnek a tünetek, őket nevezzük tünetes páciensnek $[6,7]$. A páciensek a legjobban a fájdalomtól rettegnek, ezt társítják a leginkább az emlőrák diagnózisához [7]. Az áttétes rosszindulatú betegség mind szomatikusan, mind pszichésen erôs negatív hatással bír a személyre [6].

A terápiák és gyógyszeres kezelések azok a tényezők, amelyek szintén megterhelik testileg és lelkileg a beteget.
Az alábbiakban röviden összefoglaljuk a lehetséges kezeléseket és mellékhatásaikat.

1. Emlómütét: ma már elvárás, hogy lehetőség szerint emlőmegtartó mütétre kell törekedni. Amikor ez nem kivitelezhető, az elsődlegesen alkalmazott szisztémás terápiával a tumor mérete kisebbíthető, és a mútét elvégezhető. Az onkoplasztikus szemlélet előtérbe kerülésével a tumor sebészi ellátása mellett a jó vagy kiváló esztétikai megjelenés is elvárás. Testképváltozást nemcsak a teljes emlőeltávolítás vagy azon eset okoz, amikor az emlőudvar és az emlőbimbó megtartása mellett eltávolítják az emlőállományt, hanem az is, amikor plasztikai-sebészeti korrekcióra várva a betegnél expandert helyeznek be. A test ilyen mértékű megváltozása lelki terhet ró a páciensre abban az esetben is, amennyiben lehetőség van azonnali vagy későbbi rekonstrukcióra [6-8].

2. Kemoterápiás kezelés: a kemoterápiás kezelésekhez a páciensek a leginkább a haj és a szőrzet kihullását, a hányingert és a hányást társítják. Emellett azonban még számos tünet léphet fel. Ilyen lehet a fáradékonyság, a gyengeség, a fogyás, a hasmenés, az ion- és vízháztartásnak a megváltozása. A nőiesség érzetének csökkenéséhez vezethet az is, hogy a bőrön elváltozások jelennek meg. A fiatal nők esetében a kemoterápia által kiváltott korai menopauza okozhat bőrszárazságot, nyálkahártya-szárazságot, ebből kiemelendő a hüvelyszárazság, amely hatással bír a párkapcsolatra, a szexualitásra. A testkép erôsen negatív változásai, a nóiesség sérülése mellett felerősödhet a szégyen és az izoláció érzése, és megnőhet a bizalmatlanság a kapcsolatokkal szemben [6-8].

3. Biológiai terápia: az emlőrák esetében adható biológiai terápiák jelentős mellékhatást nem okoznak a betegeknek, a terápiát a többség jól tolerálja. Természetesen a súlyosabb mellékhatások a szorongás fokozódásához vezetnek. Ilyen lehet a trasztuzumabterápia esetében a cardiotoxicitas, amely miatt a kezelést fel kell függeszteni. Vagy a bevacizumab esetében a hypertonia, a vérnyomás-ingadozások megjelenése. A triplanegatív emlőrákoknál ma már immunterápiát is alkalmaznak, amelynél endocrinopathiák jelentkezhetnek mellékhatásként. Ezek a mellékhatások szintén hatással vannak a páciens mindennapi életére $[7,8]$.

4. Hormonterápia (antihormon-kezelés): hormonterápia esetében a fiatal nőknél a korai öregedés megélése, a bőrszárazság, a körmök állagának megváltozása, a szemszárazság, a libido csökkenése - amelynek hátterében a hüvelyszárazság áll -, a gyakori vizelések és a ráncok megjelenése okozhat pszichés problémát. Emellett még jelentkezhet a klimaxra jellemző tünetek sokkal fokozottabb megnyilvánulása, ami hőhullámokkal, alvászavarral, hangulatingadozással járhat $[7$, 8]. A leggyakrabban a szexuális és érzelmi zavarokra panaszkodnak a hormonterápiában részesülő nők [9]. 
A betegség a nőiesség és az anyaság szimbólumát érinti, és ez negatív hatással lehet a párkapcsolat múködésére érzelmi és szexuális téren egyaránt $[6,7]$.

\section{Felnőttkori kötődés, párkapcsolati és szexuális elégedettség}

John Bowlby [10] definíciója szerint a kötődés a kisgyermeknek az az egyedi ragaszkodó magatartása, amely egy (vagy legfeljebb néhány) fontos személyre irányul, és célja a biztonság élményének átélése, a közelség fenntartása, valamint a félelem vagy distressz esetén vigaszt és támaszt nyújtó biztos menedék megtapasztalása. Bowlby elméletére alapozva és azt kiterjesztve Hazan és Shaver [11] elsóként alkalmazták a kötődéselméletet a felnőttkori kapcsolatokra. Megfigyeléseik szerint a felnőtt kapcsolati partnerek közötti interakciók több szempontból is hasonlóságot mutatnak a gyermekek és gondozóik közötti interakciókhoz. Ám a romantikus szerelem különbözik a gyermekkori és más felnőttkori kapcsolatoktól abban, hogy a kötődés és a gondoskodás együtt jár a szexuális vonzódással $[12,13]$.

A korábbi kötődési kapcsolatok tapasztalatai nyomán a személyben általánosított mentális reprezentációk, vagyis belső munkamodellek alakulnak a fontos másik elérhetőségéről, válaszkészségéről, kettejük kapcsolatáról és benne saját magáról [14]. A felnőttkori kötődésnek a Bartholomew és Horowitz [15] által leírt modellje két dimenzióra (szorongás, elkerülés) és négy kategóriára (biztonságos, elutasító-elkerülö, ambivalens és szorongó-elkerülő) épül, s alapja a szelf és a másik közötti kapcsolat észlelése [16]. A 'negatív szelf' modell magasabb szorongással, a 'negatív másik' modell magasabb elkerülési tendenciával jellemezhető [17]. A felnőttkori kötődés és a párkapcsolati minőség kölcsönös összefüggéseit az elmúlt évtizedekben számos vizsgálat igazolta [18]. A biztos és a bizonytalan kötődési stílusú személyek öszszehasonlításakor a biztonságosan kötődők esetében magasabb párkapcsolati elégedettséget találtak, mint a bizonytalanul kötődók esetében [19, 20]. A bizonytalan kötődésűek vizsgálataiban ugyanakkor különbség mutatkozott az elkerülő és a szorongó kötődésűek között. Az elkerülő kötődésưek esetében gyengébb kapcsolódási hajlam, a partner ritkább támogatása és alacsonyabb párkapcsolati elégedettség volt jellemző, mint a szorongó kötődésűeknél, ugyanakkor a szorongó kötődésűek esetében konfliktusra való magasabb hajlamot találtak [21]. A szexualitás a legtöbb párkapcsolatban központi szerepet játszik, a szexuális elégedettség pozitív összefüggést mutat a párkapcsolat minőségével, a párkapcsolati elégedettséggel és a személyes jólléttel [22]. Empirikus vizsgálatok sora igazolta, hogy a biztonságos kötődés hozzájárul a szexuális elégedettséghez is [23], míg szorongó és elkerülő kötődésû egyének gyakrabban számolnak be szexuális diszfunkciókról [24, 25], alacsonyabb szexuális és párkapcsolati elégedettségról [26], mint a biztonságosan kötődők.

\section{A felnőttkori kötődési stílus vizsgálatai emlőrákos betegek körében}

Az emlőrákosok körében is számos tanulmány vizsgálta már a felnőttkori kötődési stílus szerepét a betegséggel való megküzdés és az életminőség alakulásában. A biztonságos kötődés gyorsabb gyógyulási folyamattal és kevesebb - kellemetlennek, olykor elviselhetetlennek észlelt - mellékhatással van kapcsolatban, valamint magasabb poszttraumás növekedéssel és az élettel való nagyobb elégedettséggel párosul, míg a bizonytalan kötődési stílus nagyobb fokú szorongással, az elkerülő kötődési stílus pedig magasabb depressziós értékekkel jár együtt $[3,4,27,28]$. Az emlőrákos nők nagy százaléka említi azon félelmeit, hogy a betegséggel járó testi változások miatt esetleg elhagyja őket a partnerük, majd ebből fakadóan alacsonyabb önértékelésról, rosszabb mentális és testi egészségről, partnerkapcsolati és szexuális eredetű nehézségekről számolnak be. A vizsgálati eredmények alapján elmondhatjuk, hogy azok a személyek bíznak kevésbé párkapcsolatukban, akiknek kötődési stílusa bizonytalan [29-31]. Emlőrákosok alkalmazkodási nehézségeit kívánta feltárni az a kutatás, amelyben a bizonytalan kötődés elkerülő és szorongó aldimenzióinak az életminőséggel való kapcsolatát vizsgálták. A kutatók azt találták, hogy az elkerülő dimenzió pozitív összefüggést mutat az érzelmek elnyomásával és negatív kapcsolatot az életminőséggel. A szorongó kötődési dimenzió egyetlen változóval sem mutatott összefüggést [32]. A szerzők úgy vélik, hogy az elkerülő kötődési stílus sok esetben akadályozhatja a betegséghez való alkalmazkodás folyamatát, mivel ezek a személyek nem engedik meg maguknak az érzelmek kinyilvánítását. Sok esetben az orvosi és szociális támogatás is akadályokba ütközik ezeknél az egyéneknél, mivel kérdésessé válhat, hogy képesek-e másokkal kapcsolatba lépni [32]. Az eddigi eredmények tehát rámutatnak arra, hogy a betegség pozitív lefolyásának érdekében fontos figyelemmel kísérni a rákbetegséggel küzdők kötődési mintázata, kapcsolati jellemzői és a pszichés folyamatok közötti összefüggéseket [31-34].

\section{A vizsgálat célja}

Már az eddigi, emlőrákosok körében végzett kötődésvizsgálatok is a pszichés összefüggéseket elemezték, kutatva a lehetőségeket, amelyek a betegség pozitív kimeneteléhez segíthetik a betegeket. A szakirodalomban található kutatási eredmények azonban - klinikai és nem klinikai populációt vizsgálva - néha ellentmondásosak abból a szempontból, hogy a kötődés mely dimenzióit találták szignifikáns tényezőnek a párkapcsolati és a szexuális elégedettség előrejelzésben [31, 33]. Hiányoznak továbbá azok a vizsgálatok, melyek magyar mintán ellenőrzik ezeket az összefüggéseket. Jelen munkánkban újabb adatokkal szeretnénk hozzájárulni a kutatásokhoz azzal, hogy emlőrákkal küzdő nők párkapcsolati és sze- 
xuális elégedettségét, valamint kötődésük sajátosságait, ezen belül az 'elkerülés' és 'szorongás' dimenziókat vizsgáljuk és hasonlítjuk össze egészséges kontrollcsoportéval. A két csoportnál külön-külön megvizsgáljuk a kötődési jellemzők, valamint a párkapcsolati és szexuális elégedettség közötti összefüggéseket. Hipotézisünk szerint az elkerülő és szorongó kötődési dimenziók nagymértékú negatív összefüggést mutatnak majd a kapcsolati és a szexuális elégedettséggel mind az egészséges, mind az emlőrákos nők esetében. Vizsgáljuk a két csoport mintázatai és értékei között mutatkozó esetleges különbségeket avagy hasonlóságokat, illetve ezeknek az összefüggéseknek az erősségét.

\section{Módszer}

\section{Minta}

Kutatásunk a Semmelweis Egyetem Onkológiai Központjával való szoros együttmúködés során valósult meg; a vizsgálathoz szükséges engedélyt a Semmelweis Egyetem Regionális, Intézményi Tudományos és Kutatásetikai Bizottsága adta meg, melynek száma: 98-2/2014. A vizsgált mintát 272 nő alkotta, közülük 135 személyt az előző egy évben emlődaganattal diagnosztizáltak. A teljes kérdóívcsomagot a diagnosztizált résztvevók egyik felével (93 fó) személyesen, egy másik részével (42 fó) online formában, emlődaganatos önsegítő csoportok közremúködésével vettük fel. Kontrollcsoportként a diagnózissal bíró nőkhöz korban, iskolázottságban, kapcsolati státuszban stb. illesztve 137 egészséges - vagyis emlőrákkal nem diagnosztizált - személyt választottunk ki, akik szintén online kérdőíveket töltöttek ki. A vizsgálatba való bekerülés kritériuma volt, hogy a megkérdezettek párkapcsolatban éljenek - a betegek esetében a diagnózist megelőzően, legalább három hónapnál korábban -, és aktív dolgozók legyenek. Kizáró kritérium volt egyéb betegség megléte, illetve pszichiátriai kezelésben való részvétel. A diagnosztizált résztvevők átlagéletkora 52 év, a szórás 9,7 év (min.: 30 év, max.: 80 év), a kontrollcsoport átlagéletkora 49 év, a szórás 9,3 év (min.: 31 év, max.: 72 év) volt. A diagnosztizált csoport átlagéletkora valamivel magasabb volt, mint a kontrollcsoporté, ám ez a vizsgálati eredmény csak marginálisan volt szignifikáns. A diagnosztizált csoport tagjai (135 fö) közül 82 fó $(63,1 \%)$ házasságban, 22 fó $(16,9 \%)$ tartós élettársi kapcsolatban, 41 fó $(14,6 \%)$ párkapcsolatban és 7 fö $(5,4 \%)$ egyedül él. 93 fó felső-, $(70 \%), 27$ fö közép$(20,3 \%)$ és 13 fó $(9,8 \%)$ alapfokú végzettséggel rendelkezik. A kontrollcsoportban 100 fó (73\%) házasságban, 32 fó $(23,4 \%)$ tartós élettársi kapcsolatban és 5 fó $(3,7 \%)$ párkapcsolatban él. 66 fó felső- $(48,2 \%), 45$ fö közép$(32,8 \%)$ és 26 fó (19\%) alapfokú végzettséggel rendelkezik.

A diagnosztizált csoport betegséggel kapcsolatos változói közül a tesztfelvétel idején már megtörtént vagy épp aktuális terápiák (mütét, kemo-, sugárterápia vagy egyéb kezelés), a mútét típusa (mastectomia vagy emlőmegtartó mútét), illetve a jelenlegi betegségstátusz (primer daganatos-e, vagy már felfedeztek távoli áttétet) információit elemeztük. Mintánkban a diagnosztizált csoport 19,4\%-a küzdött áttétes betegséggel. A teljes diagnosztizált minta 68,7\%-a kemo-, 62,7\%-a sugár-, 46,3\%-a antihormon-, 17,9\%-a biológiai és 4,5\%-a immunterápiában részesült. Mastectomia a minta $62,3 \%$ ánál, emlőmegtartó mütét pedig 29,5\%-nál történt.

\section{Eszközök}

A szorongó és elkerülő kötődési dimenziók mérésére a felnőttkori kötődést mérő RSQ-H hétkérdéses, rövidített változatát alkalmaztuk [35]. A szorongó kötődési dimenzió, amely az elhagyástól és a visszautasítástól való félelemre utal, négy tételből állt (például „Szeretnék nagyon szoros, bensőséges kapcsolatot kialakítani másokkal, de gyakran úgy találom, hogy mások vonakodnak olyan közel kerülni hozzám, ahogy azt én szeretném”), az elkerülő kötődés három tételt tartalmazott (például „Nem aggaszt, ha egyedül vagyok, vagy ha mások nem fogadnak el"). A válaszadók ötfokozatú, Likert típusú skála segítségével jelölték, hogy az adott állítással milyen mértékben értenek egyet. A két alskála belső konzisztenciája a mintánkon megfelelőnek bizonyult, a Cronbach- $\alpha$ értéke a szorongó alskála esetében 0,744, az elkerülőnél 0,640-es értéket mutatott.

A kapcsolati elégedettséget a hét kérdésből álló Kapcsolati Elégedettség Skála magyar változatával - RAS-H [36] - mértük fel (például „Milyen mértékben felel meg a kapcsolatuk az Ön eredeti elvárásainak?" 1 = kevéssé, 5 = nagyon). A skála kiváló megbízhatósággal rendelkezett; a Cronbach- $\alpha$ értéke a teljes mintán 0,920 volt.

A szubjektív egészségi állapot $(1=$ nagyon rossz; 5 = kiváló) mérésére egy tétel szolgált.

A szexuális elégedettség nagymértékű összefüggést mutat a szakirodalom szerint [37] a kapcsolati elégedettséggel, ugyanakkor az emlődaganatos beteg tünetei, a nőiesség megváltozása (például mastectomia), valamint a kezelések mellékhatásai (például a haj elvesztése, rosszullétek) szintén jelentősen befolyásolhatják. E kérdéskör megvizsgálására a teljes mintánkból kiválasztott 190 fơs almintán (77 emlőrákos és 113 egészséges nő) szintén egy tételt alkalmaztunk a szexuális elégedettség mértékének ( 1 = alacsony; 5 = kiváló) megállapítására. A további elemzések során a szubjektív egészségi állapot és a szexuális elégedettség öt kategóriáját a könnyebb kezelhetőség érdekében háromkategóriássá alakítottuk (alacsony, közepes és jó egészségi állapot, valamint alacsony, közepes és magas szexuális elégedettség).

\section{Statisztikai módszerek}

A statisztikai elemzéseket az IBM SPSS statisztikai programcsomag 22. verziójával (IBM Corporation, Armonk, NY, Amerikai Egyesült Államok) végeztük. Kétmintás 
t-próbákkal és khi-négyzet-próbákkal vizsgáltuk a diagnosztizált és az egészséges csoport közti különbségeket a kötődési dimenziók (szorongó és elkerülő), a kapcsolati elégedettség, a kor, a szubjektív egészségi állapot és a szexuális elégedettség tekintetében. A hipotézisek ellenőrzésére többszörös lineáris regressziós elemzést alkalmaztunk, a kapcsolati elégedettség volt a függő változónk. A résztvevők egy almintáján, akik körében a szexuális elégedettséget is vizsgáltuk, multinomiális logisztikus regressziós elemzéseket végeztünk, ekkor a három fokozatból álló szexuális elégedettség volt a függő változó (az alacsony pontszámok szolgáltak referenciakategóriaként). A prediktor változók minden esetben 'enter' módszerrel kerültek beléptetésbe a modellekbe.

\section{Eredmények}

Majdnem minden vizsgált változó mentén különbségek mutatkoztak az emlőrákkal diagnosztizált nők és a kontrollcsoport között. A kétmintás t-próbák eredményei szerint a diagnosztizált csoport körében magasabb volt az elkerülő kötődés, és kevésbé voltak elégedettek a kapcsolatukkal, ugyanakkor a szorongó kötődési stílus tekintetében nem mutatkozott különbség a két csoport között. A khi-négyzet-próbák további különbségeket tártak fel a csoportok között; a diagnosztizált csoport általában véve rosszabbnak ítéli egészségi állapotát $\left(\chi^{2}(2,270)=27,803, p<0,001\right)$, és kevésbé elégedett szexuális életével $\left(\chi^{2}(2,190)=35,613, \mathrm{p}<0,001\right)$ (1. táblázat).
Az eddigi szakirodalmi adatokat, valamint előzetes elemzéseink eredményeit alapul véve hipotéziseink többváltozós vizsgálatára regressziós elemzéseket végeztünk (2. táblázat). A regressziókat interakciós taggal is lefuttattuk: a diagnózis szerinti státusz szorzatát képeztük először a szorongó, majd az elkerülő dimenzióval, és a szorzatot is a regressziós egyenletbe bocsátottuk. Ezekkel a kiegészítő elemzésekkel ellenőriztük, hogy a modell eltérően múködik-e a diagnózissal rendelkező és az egészséges mintán. Mivel az interakciós tagok nem voltak szignifikánsak, azaz a diagnózis meglétének nem volt a modellben moderációs hatása, a továbbiakban nem kezeltük külön a mintákat az elemzések során. Az alábbiakban a teljes mintán nyert összefüggéseket mutatjuk be, melyek a fentieknek megfelelően mindkét almintára egyaránt érvényesek. (Kérésre a kiegészítő elemzéseket megküldjük az érdeklődőknek.)

Kapcsolati elégedettség: A többszörös regressziós modellben, kontrollváltozókként bevonva az életkort és a szubjektív egészségi állapotot, a szorongó $(\beta=-0,199, \mathrm{p}$ $=0,001)$ és az elkerülő $(\beta=-0,146, \mathrm{p}=0,015)$ kötődési dimenzió az alacsonyabb kapcsolati elégedettséget szignifikánsan, fordított irányban jelzi előre. További eredmények szerint a jó (jó vs. rossz) szubjektív egészségi állapot $(\beta=0,213, p=0,053)$ szintén összefüggésben áll a kapcsolati elégedettséggel. A vizsgált változók a teljes modell varianciájának $13,6 \%$-át magyarázzák $(F(6,263)$ $=6,87, \mathrm{p}<0,001)$.

Szexuális elégedettség: Multinomiális logisztikus regressziós modellekben a közepes (vs. alacsony) szexuális

1. táblázat | A két csoport összehasonlítása demográfiai jellemzőik, valamint kapcsolati és jóllétmutatók tekintetében

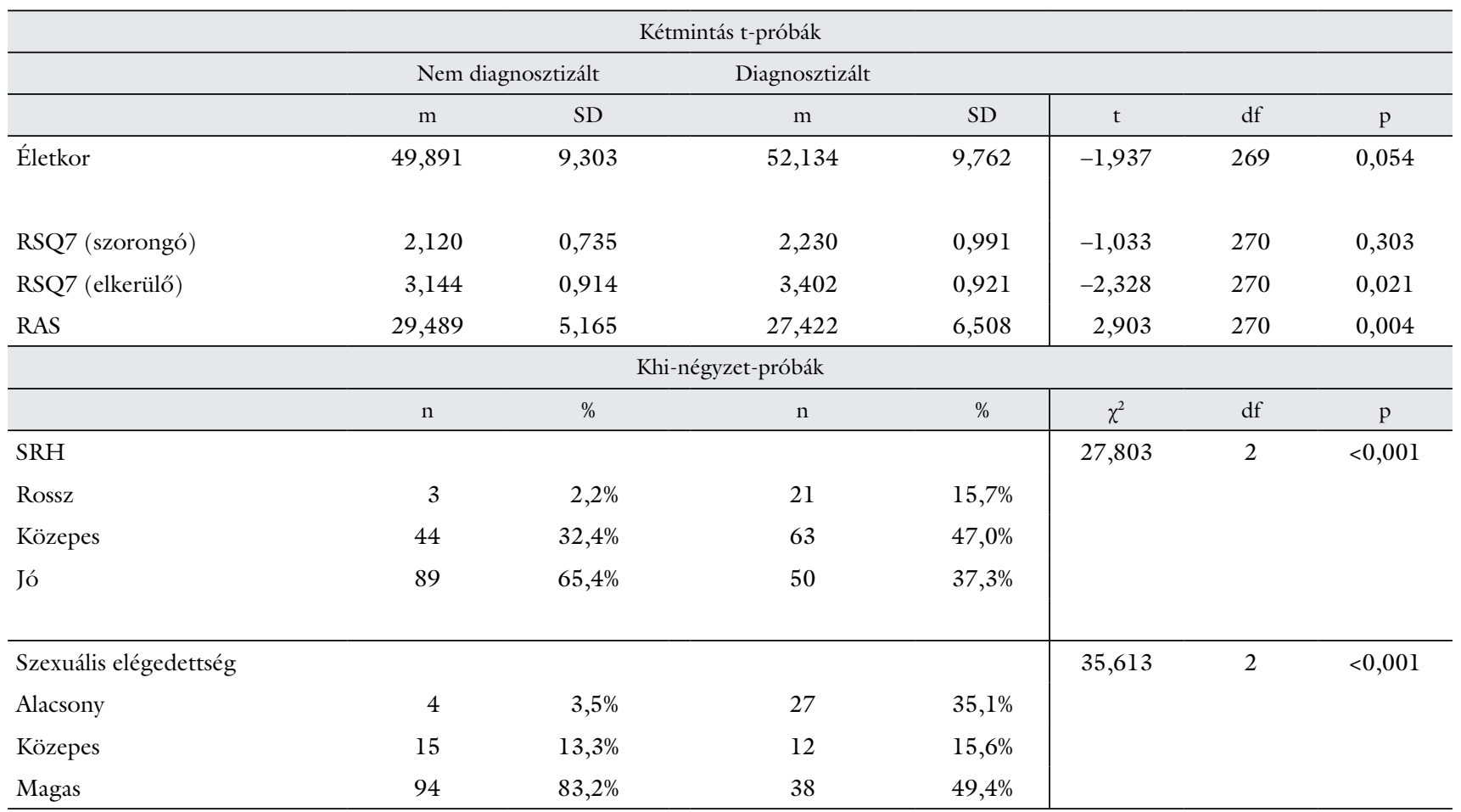

RAS = Kapcsolati Elégedettség Skála; RSQ = Kapcsolati Kérdőív; SD = standard deviáció; SRH = szubjektív egészségi állapot 
2. táblázat | Regressziós elemzések a kapcsolati elégedettségre és a szexuális elégedettségre vonatkozóan (3 fokozatú)

\begin{tabular}{|c|c|c|c|c|c|c|c|c|c|c|c|c|c|c|c|}
\hline \multirow[t]{3}{*}{$\begin{array}{l}\text { Függő } \\
\text { változó }\end{array}$} & \multicolumn{3}{|c|}{ RAS } & \multicolumn{4}{|c|}{$\begin{array}{l}\text { Szexuális elégedettség } \\
\text { (közepes vs. alacsony) }\end{array}$} & \multicolumn{4}{|c|}{$\begin{array}{l}\text { Szexuális elégedettség } \\
\text { (magas vs. alacsony) }\end{array}$} & \multicolumn{4}{|c|}{$\begin{array}{l}\text { Szexuális elégedettség } \\
\text { (magas vs. közepes) }\end{array}$} \\
\hline & \multirow[t]{2}{*}{ B } & \multirow[t]{2}{*}{$\beta$} & \multirow[t]{2}{*}{$\mathrm{p}$} & \multirow[t]{2}{*}{ OR } & \multicolumn{2}{|c|}{$\mathrm{CI}$} & \multirow[t]{2}{*}{$\mathrm{p}$} & \multirow[t]{2}{*}{ OR } & \multicolumn{2}{|c|}{$\mathrm{CI}$} & \multirow[t]{2}{*}{$\mathrm{p}$} & \multirow[t]{2}{*}{ OR } & \multicolumn{2}{|c|}{$\mathrm{CI}$} & \multirow[t]{2}{*}{$\mathrm{p}$} \\
\hline & & & & & lower & upper & & & lower & upper & & & lower & upper & \\
\hline Életkor & 0,047 & 0,076 & 0,210 & 0,981 & 0,924 & 1,041 & 0,522 & 1,002 & 0,957 & 1,049 & 0,943 & 1,002 & 0,957 & 1,049 & 0,943 \\
\hline $\begin{array}{l}\text { Diagnózis } \\
\text { (igen } v s . \\
\text { nem) }\end{array}$ & $-1,214$ & $-0,102$ & 0,096 & 6,144 & 1,484 & 25,434 & 0,012 & 11,815 & 3,574 & 39,051 & $<0,001$ & 11,815 & 3,574 & 39,051 & $<0,001$ \\
\hline $\begin{array}{l}\text { SRH } \\
\text { (közepes } \\
\text { ps. } \\
\text { alacsony) }\end{array}$ & 0,634 & 0,052 & 0,624 & 1,195 & 0,232 & 6,151 & 0,831 & 0,742 & 0,214 & 2,572 & 0,638 & 1,348 & 0,389 & 4,671 & 0,638 \\
\hline $\begin{array}{l}\text { SRH } \\
\text { (jó vs. } \\
\text { alacsony) }\end{array}$ & 2,540 & 0,213 & 0,053 & 0,227 & 0,035 & 1,471 & 0,120 & 0,178 & 0,038 & 0,831 & 0,028 & 0,241 & 0,071 & 0,820 & 0,023 \\
\hline $\begin{array}{l}\text { RSQ7 } \\
\text { (szorongó) }\end{array}$ & $-1,363$ & $-0,199$ & 0,001 & 1,021 & 0,549 & 1,897 & 0,948 & 0,901 & 0,542 & 1,496 & 0,686 & 0,901 & 0,542 & 1,496 & 0,686 \\
\hline $\begin{array}{l}\text { RSQ7 } \\
\text { (elkerülő) }\end{array}$ & $-0,944$ & $-0,146$ & 0,015 & 1,594 & 0,813 & 3,125 & 0,175 & 1,368 & 0,784 & 2,388 & 0,270 & 1,368 & 0,784 & 2,388 & 0,270 \\
\hline
\end{tabular}

CI = konfidenciaintervallum; RAS = Kapcsolati Elégedettség Skála; RSQ = Kapcsolati Kérdőív; SRH = szubjektív egészségi állapot

elégedettséget szignifikánsan jelzi előre az a tény, ha valaki rákdiagnózissal rendelkezik $(\mathrm{p}=0,012)$, míg a kötődési stílus nem mutat összefüggést a szexuális elégedettséggel. A második és a harmadik modellben a szexuális elégedettséget (magas vs. alacsony és magas vs. közepes szexuális elégedettség) szintén előre jelzi a diagnózis megléte (fordított irányú összefüggés), ezekben a modellekben azonban a szubjektíven jobbnak ítélt egészségi állapot szintén összefüggésben áll a szexuális élettel való elégedettséggel ( $\mathrm{p}_{\text {magas-alacsony }}=0,028$ és $\mathrm{p}_{\text {magas-közepes }}=$ $0,023)$. Ám a két kötődési dimenzió, a szorongó és az elkerülő kötődés ismét nem bizonyult szignifikáns prediktor változónak.

\section{Megbeszélés}

Korábbi kutatások a kapcsolati jellemzők, a pszichés folyamatok és az elkerülő és szorongó kötődési dimenziók közötti összefüggéseket vizsgálták emlőrákos nőknél a betegség pozitív kimenetele érdekében [31-34]. Végeztek vizsgálatokat hasonló témában a nem klinikai populációkon is, de a két (beteg és egészséges) csoport összehasonlítása nem mindenhol került fókuszba.

Jelen vizsgálatunkban emlőrákkal diagnosztizált, párkapcsolatban élő nók és a hozzájuk korban és életviteli státuszban illesztett kontrollcsoport egészségi állapotát, párkapcsolati és szexuális elégedettségének minőségét vizsgáltuk a felnőttkori kötődés alapvető jellemzőivel, azaz a kötődési szorongás és a kötődési elkerülés dimenzióival összefüggésben. Eredményeink összességében arra utalnak, hogy az emlőrákkal diagnosztizált nők mind kötődési jellemzőik, mind pedig párkapcsolatuk múködése szempontjából sebezhetőbbek egészséges társaiknál.

\section{Az alminták összehasonlitása}

Egyrészt azt találtuk, hogy a diagnosztizált nők körében magasabb volt az elkerülő kötődés, azaz az a kapcsolódási tendencia, amikor a biztonság elsősorban a fontos másik személyről való érzelmi leválásban található meg. Ez olyan állításokra adott magasabb pontszámban jelent meg, mint például „Nagyon fontos számomra, hogy függetlennek és önállónak érezzem magam”.

Az elkerülő kötődésű személyekre jellemző, hogy önmagukról pozitívan gondolkodnak, de másokkal szemben bizalmatlanok, a róluk való gondolkodásuk negatív, ezért inkább függetlenségre törekednek, és hangsúlyozzák, hogy nincs szülkségük az intimitásra [13]. A diagnosztizált nőkre jellemző lehet az érzelmi sérülékenység, és az elhagyatástól való félelem miatt párkapcsolatukban bizalmatlanná válhatnak. A feltételezett csalódás elkerülése érdekében inkább független és önálló viselkedésformát mutatnak. Az elkerülő kötődésúek nagyobb száma abból is adódhat, hogy a betegség következtében elvárt, de meg nem kapott támogatás a másokról kialakult (addig pozitív) gondolkodást, véleményt negatív irányba változtathatja meg [38].

A szorongó kötődés tekintetében - amely olyan állításokban jelent meg kutatásunkban, mint például „Szoros érzelmi kapcsolatokat szeretnék, de nebezemre esik, hogy tökéletesen megbizzak másokban, vagy, hogy függjek tö- 
lük” - viszont nem mutatkozott szignifikáns különbség a két csoport között.

A szorongó kötődésû személyekre jellemző, hogy sem önmagukról, sem pedig másokról nem gondolkodnak pozitívan, másokkal szemben bizalmatlanok [19]. Vizsgálatunk eredménye alapján a mintánkban szereplő egészségesek között hasonló mértékben vannak szorongó kötődésű személyek, mint a diagnosztizáltak között. Úgy tûnik, hogy a diagnosztizált csoportban a betegség nem befolyásolja az eleve negatív véleményt önmagukról és a fontos másikról.

A diagnosztizált mintában kevésbé voltak a nők elégedettek a párkapcsolatukkal. Mivel azonban a diagnózis megléte a többváltozós elemzések során már nem függött össze szignifikánsan a kapcsolati elégedettséggel, a talált összefüggések lehetséges értelmezése több, korábbi kutatás eredményével is magyarázható, mivel az emlőrákos nóknél a betegségükkel való összefüggésben több szerző is felhívja a figyelmet a megváltozott interperszonális és kommunikációs viszonyokra. A betegségben szenvedő nők a legtöbbször kerülik párkapcsolatukban a betegségről való beszélgetést, igényeiket nem kommunikálják nyíltan, úgy vélik, az addig róluk alkotott vélemény megváltozott, s mindez elszigetelődéshez, társas izolációhoz, párkapcsolati elégedetlenséghez vezethet [38-40].

A két csoport között különbséget találtunk végül az egészségi állapot és a szexuális élettel való elégedettség átlagos szintjében is: az emlőrákkal diagnosztizált nók szubjektíven kevésbé ítélik jónak egészségüket, és inkább elégedetlenek szexuális életükkel. Ez az eredmény jól magyarázható azzal, hogy a betegség miatt jelentkező félelmek (például halálfélelem) vagy a betegség folyamán fellépő testi változások (például az emlő vagy a haj elvesztése), a kezelések milyensége (például kemoterápia, mütét, antihormon-kezelés) és az azokkal járó mellékhatások elviselése (például émelygés, fájdalmak) szubjektív értelemben is rosszabb egészségi állapotot idézhetnek elő, illetve hosszabb-rövidebb időre befolyásolhatják a libidót. Érdemes azonban emellett arra is utalni, hogy a szubjektív egészségi állapot mutatója a kutatások szerint sokféle tapasztalatot sûrít egyetlen általános értékelésbe: nem csupán testi állapotukat reprezentálják ilyen módon a válaszadók, hanem a számukra elérhető testi és lelki erőforrások összességét, mint az érzelmi jóllétet vagy a társas támogatottság meglétét is [41]. A diagnosztizált minta alacsonyabb értéke ezért arra utal, hogy a betegséggel való küzdelem nemcsak a testi egészség érzetére lehet hatással, hanem tágabb értelemben is csökkentheti a nők azon élményét, hogy rendelkezésükre állnak korábbi erőforrásaik.

\section{A kapcsolati és szexuális elégedettség prediktorai}

A két alminta jellemzőinek összehasonlítása mellett fontos célja volt a kutatásnak az is, hogy megvizsgáljuk, milyen összefüggésben állnak a kötődési jellemzők a párkapcsolati és szexuális elégedettséggel. Mivel az elemzések során nem találtunk szignifikáns moderációs hatást a diagnózis megléte szempontjából, a teljes mintán nyert összefüggéseket érvényesnek tekinthetjük mind az emlőrákkal diagnosztizált, mind pedig az egészséges nők párkapcsolati múködése szempontjából. Ez az eredmény értelmezhető úgy, hogy a diagnózis ténye, illetve az ezzel járó változások önmagukban nem változtatják meg a kapcsolatok alapvető müködésének módját. Viszont, mint azt az eredményekből láthatjuk, hatással lehetnek a konkrét tapasztalatokra, a kapcsolat minóségi jellemzöire.

Többváltozós elemzéseink alapján elmondható, hogy minél jobbnak ítéli az egyén az egészségi állapotát, minél inkább jellemző a személyre a biztonságos kötődés és minél kevésbé az elkerülő vagy a szorongó kötődés, annál nagyobb a kapcsolati elégedettsége. Ez az összefüggés megerősíti az általános felnőtt [19, 20], illetve az emlődaganatos mintákon végzett korábbi kutatások eredményeit [29-31]: azok a diagnosztizált nók, akikre jellemzőbb a szorongó, illetve az elkerülő kötődés, kevésbé elégedettek párkapcsolatukkal, ami megegyezik a szakirodalomban leírtakkal [31, 32, 41]. A többváltozós elemzés egyúttal azt is jelezte, hogy a diagnózis megléte, a többi változóra kontrollálva, már nem jelzi előre a kapcsolati elégedettséget. A két alcsoport között a kapcsolati elégedettségben talált különbség ezek szerint jelentős részben visszavezethető a kötődési jellemzőknek a csoportok közötti eltérésére. Ebből jelen vizsgálatunkban, mint láthattuk, elsősorban az elkerülés magasabb szintjét sikerült igazolni a diagnosztizált csoportban.

A párkapcsolati elégedettséggel ellentétben a kötődési dimenziók nem jelezték előre a szexuális elégedettséget; vagyis az, hogy valakire mennyire jellemző a szorongó, illetve az elkerülő kötődési dimenzió, valószínúleg nem közvetlen befolyásoló tényező a szexuális örömképesség szempontjából. Ez az eredményünk egy korábbi, nem klinikai mintán végzett vizsgálat eredményeihez hasonló mintázatot mutat, amelynél a felnőttkori kötődés szorongó és elkerülő dimenziója nem volt közvetlen hatással a szexuális elégedettségre. A szerzők magyarázata szerint a felnőttkori kötődés a szexuális elégedettségre a szexuális kommunikáció közvetett útján, illetve azon keresztül lesz igazán meghatározható [42]. Érdemes lehet a további kutatásokban figyelembe venni az egyéni jellemzőket is, például az élettel való elégedettséget vagy a depresszivitás mértékét, mivel ezek az egyéni tapasztalatok a korábbi kutatásokban egyfelől összefüggést mutattak a kötődési dimenziókkal [vö. 3, 4, 27, 28], másrészt közvetítő tényezőként befolyásolhatják a kapcsolati múködéseket, így a szexuális elégedettséget is.

\section{A kutatás korlátai}

Kutatásunknak természetesen vannak korlátai, melyeket az eredmények értelmezésekor figyelembe kell venni. Ilyen korlát például, hogy mivel keresztmetszeti és korrelációs kutatási megközelítést alkalmaztunk, a talált ösz- 
szefüggések nem igazolnak ok-okozati viszonyokat a vizsgált változók között. Korlátokat rejt magában az is, hogy a felhasznált kérdőívek közül néhány esetben (mint például az RSQ, azaz a felnőttkori kötődést mérő kérdőív esetében) a rövidített változatot használtuk, aminek negatív hatása lehet a mérések pontosságára és így a belőlük levonható következtetések érvényességére. Végül érdemes megemlíteni a mintaválasztás korlátait is. Mind a diagnosztizált, mind a kontrollminta esetében az egészségi státusz meghatározása csupán önbevalláson alapult. Továbbá mindkét alminta viszonylag heterogén volt, ami felveti annak lehetôségét, hogy jelentősen különböző tapasztalatokkal rendelkező válaszadókat tekintettünk egységes csoportnak. Egy következő munkában javasolt ezen korlátozó tényezők kiküszöbölése és az itt bemutatott összefüggések részletes ellenőrzése.

\section{Következtetések}

Tanulmányunk a korábbi kutatásokhoz hasonlóan kimutatta, hogy az emlőrákkal diagnosztizált nők kötődési mintázatai szerepet játszanak a párkapcsolati elégedettségük alakulásában, amely viszont befolyásolhatja a betegséggel való megküzdésüket. Ez az eredmény felhívja a figyelmet arra, hogy fontos megismernünk a rákbeteg személy kötődési mintázatait annak érdekében, hogy egyénre szabott, hatékonyabb intervenciókat lehessen kialakítani és felajánlani a betegek és optimális esetben a partnerük számára. Eredményeink arra utalnak, hogy a célzott terápiák közül célszerü lehet a kapcsolati készségek fejlesztése, ami így magasabb párkapcsolati elégedettséghez vezethet. A Magyarországon is egyre inkább ismert, érzelemfókuszú párterápiás megközelítés (emotionally focused therapy) például kifejezetten a kötődési mintázatok fejlesztését állítja a középpontba [43]. Végső soron pedig a páciensek testi, lelki és kapcsolati jellemzőinek figyelemmel kísérése és támogatása hozzájárulhat a jobb életminőség eléréséhez.

Anyagi támogatás: Ezt a kutatást részben az Országos Tudományos Kutatási Alapprogramok (OTKA) támogatta. A támogatás száma: PD 105685.

Szerzői munkamegosztás: D. J., M. T.: A kutatási folyamat koncepciójának kidolgozása és felügyelete. D. J., L. Cs., Cs. S. I.: A hipotézisek kidolgozása, a vizsgálat megszervezése, az adatgyưjtés szervezése és lebonyolítása, az eredmények értelmezése és a kézirat szövegezése. D. M., M. T., S. V.: Az eredmények értelmezése és a kézirat szövegezése. Cs. S. I., F. O., M. T.: A kutatás statisztikai elemzése, az eredmények értelmezése és a tanulmány szövegezése. A cikk végleges változatát valamennyi szerző elolvasta és jóváhagyta.

Érdekeltségek: A szerzők között nincs összeférhetetlenség. A szerzőknek nincsenek érdekeltségeik.

\section{Irodalom}

[1] Nissim R, Hales S, Zimmermann C, et al. Supporting family caregivers of advanced cancer patients: a focus group study. Fam Relat. 2017; 66: 867-879.

[2] Pitceathly C, Maguire P. The psychological impact of cancer on patients' partners and other key relatives: a review. Eur J Cancer 2003; 39: 1517-1524.

[3] Naaman S, Radwan K, Johnson S. Coping with early breast cancer: couple adjustment processes and couple-based intervention. Psychiatry 2009; 72: 321-345.

[4] Nissen KG. Correlates of self-rated attachment in patients with cancer and their caregivers: a systematic review and meta-analysis. Psychooncology 2016; 25: 1017-1027.

[5] Kimmel PL, Peterson RA, Weihs KL, et al. Dyadic relationship conflict, gender, and mortality in urban hemodialysis patients. J Am Soc Nephrol. 2000; 11: 1518-1525.

[6] Riskó Á. Body, soul and tumor: introduction to oncopsychology. [A test, a lélek és a daganat: bevezetés az onkopszichológiába.] Animula Kiadó, Budapest, 1999. [Hungarian]

[7] Dank M. Fatigue. In: Horti J, Riskó Á. (eds.) Oncopsychology in practice. II. [Fáradtság. In: Horti J, Riskó Á. (szerk.) Onkopszichológia a gyakorlatban. II.] 2017; pp. 317-327. [Hungarian]

[8] Gehl J. About breast cancer personally. [Az emlőrákról személyesen.] Medicina Könyvkiadó, Budapest, 2003; pp. 24-67. [Hungarian]

[9] Pumo V, Milone G, Iacono M, et al. Psychological and sexual disorders in long-term breast cancer survivors. Cancer Manag Res. 2012; 4: 61-65.

[10] Bowlby J. A secure base: clinical applications of attachment theory. Brunner-Routledge, London, 1988.

[11] Hazan C, Shaver PR. Romantic love conceptualized as an attachment process. J Pers Soc Psychol. 1987; 52: 511-524.

[12] Fraley RC, Shaver PR. Adult romantic attachment: theoretical developments, emerging controversies, and unanswered questions. Rev Gen Psychol. 2000; 4: 132-154.

[13] Mikulincer M, Shaver PR. Attachment in adulthood. Structure, dynamics, and change. Guilford Press, New York-London, 2016.

[14] Brennan KA, Clark CL, Shaver PR. Self-report measurement of adult attachment: An integrative overview. In: Simpson JA, Rholes WS. (eds.) Attachment theory and close relationships. Guilford Press, New York, 1998; pp. 46-76.

[15] Bartholomew K, Horowitz LM. Attachment styles among young adults: A test of four-category model. J Pers Soc Psychol. 1991; 61: 226-244.

[16] Onishi M, Gjerde PF, Block J. Personality implications of romantic attachment patterns in young adults: a multi-method, multiinformant study. Pers Soc Psychol Bull. 2001; 27: 1097-1110.

[17] Johnson SM. The practice of emotionally focused couple therapy: creating connection. Brunner-Routledge, New York, NY, 2004.

[18] Feeney JA. Adult romantic attachment: developments in the study of couple relationships. In: Cassidy J, Shaver PR. (eds.) Handbook of attachment: theory, research, and clinical applications. 2nd edn. Guilford Press, New York, NY, 2008; pp. 456481.

[19] Mikulincer M, Shaver PR. An attachment perspectives on family relations. In: Fiese $\mathrm{BH}$, Celano $\mathrm{M}$, Deater-Deckard $\mathrm{K}$, et al. (eds.) APA Handbooks in Psychology Series. APA Handbook of Contemporary Family Psychology: Foundations, Methods, and Contemporary Issues Across The Lifespan. American Psychological Association, Washington, DC, US, 2019; pp. 109-125.

[20] Siegel A, Levin Y, Solomon Z. The role of attachment of each partner on marital adjustment. J Fam Issues 2018; 40: 415-434. 
[21] Li T, Chan, DK. How anxious and avoidant attachment affect romantic relationship quality differently: a meta-analytic review. Eur J Soc Psychol. 2012; 42: 406-419.

[22] Brassard A, Dupuy E, Bergeron S, et al. Attachment insecurities and women's sexual function and satisfaction: the mediating roles of sexual self-esteem, sexual anxiety, and sexual assertiveness. J Sex Res. 2013; 52: 110-119.

[23] Mark KP, Vowels LM, Murray SH. The impact of attachment style on sexual satisfaction and sexual desire in a sexually diverse sample. J Sex Marital Ther. 2018; 44: 450-458.

[24] Brassard A, Shaver PR, Lussier Y. Attachment, sexual experience, and sexual pressure in romantic relationships: a dyadic approach. Pers Relat. 2007; 14: 475-493.

[25] Özcan Ö, Cumurcu Elbozan B, Karlidağ R, et al. Attachment styles in women with vaginismus. Anat J Psychiatry 2015; 16 : $37-43$.

[26] Butzer B, Campbell L. Adult attachment, sexual satisfaction, and relationship satisfaction: a study of married couples. Pers Relat. 2008; 15: 141-154

[27] Cordova JV, Gee CB, Warren LZ. Emotional skillfulness in marriage: intimacy as a mediator of the relationship between emotional skillfulness and marital satisfaction. J Soc Clin Psychology $2005 ; 24: 218-235$

[28] Nicholls W, Hulbert-Williams N, Bramwell R. The role of relationship attachment in psychological adjustment to cancer in patients and caregivers: a systematic review of the literature. Psychooncology 2014; 23: 1083-1095.

[29] Ávila M, Coimbra JL, Park CL, et al. Attachment and posttraumatic growth after breast cancer: a dyadic approach. Psychooncology 2017; 26: 1929-1935.

[30] Fobair P, Stewart SL, Chang S, et al. Body image and sexual problems in young women with breast cancer. Psychooncology 2006; 15: 579-594.

[31] Ávila M, Brandão T, Coimbra JL, et al. Experiencing an intimate partner's breast cancer: attachment, caregiving, and burden in men. Psychiatry 2016; 79: 236-248.

[32] Schmidt SD, Blank TO, Bellizzi KM, et al. The relationship of coping strategies, social support, and attachment style with posttraumatic growth in cancer survivors. J Health Psychol. 2012; 17: 1033-1040.

[33] De Luca R, Dorangricchia P, Salerno L, et al. The role of couples' attachment styles in patients' adjustment to cancer. Oncology 2017; 92: 325-334.
[34] Désfalvi J, Hámori E, Horváth J, et al. Attachment, early maladaptive schemas and subjective experiences of illness in woman with breast cancer. [Kötődés, korai maladaptív sémák és szubjektív betegségélmény emlőrákkal küzdő nôknél.] Magy Pszichol Szle. 2017; 72: 127-145. [Hungarian]

[35] Csóka Sz, Szabó G, Sáfrány E, et al. An experiment to measure adult attachment - Relationship Scale Questionnaire. [Kísérlet a felnőttkori kötődés mérésére - A Kapcsolati Kérdőív (RSQ) magyar változata.] Pszichológia 2007; 27: 333-354. [Hungarian]

[36] Martos T, Sallay V, Szabó T, et al. Psychometric characteristics of the Hungarian version of the Relationship Assessment Scale (RAS-H). [A Kapcsolati Elégedettség Skála magyar változatának (RAS-H) pszichometriai jellemzői.] Mentálhig Pszichoszom. 2014; 15: 245-258. [Hungarian]

[37] Casellas-Grau A, Font A, Vives J. Positive psychology interventions in breast cancer. A systematic review. Psychooncology 2014; 23: 9-19.

[38] Donovan-Kicken E, Caughlin JP. A multiple goals perspective on topic avoidance and relationship satisfaction in the context of breast cancer. Communication Monographs 2010; 77: 231-256.

[39] Wortman CB. Social support and the cancer patient: Conceptual and methodologic issues. Cancer 1984; 53: 2339-2360.

[40] Peters-Golden H. Breast cancer: Varied perceptions of social support in the illness experience. Soc Sci Med. 1982; 16: 483-491.

[41] Bailis DS, Segall A, Chipperfield JG. Two views of self-rated general health status. Soc Sci Med. 2003; 56: 203-217.

[42] Timm TM, Keiley MK. The effects of differentiation of self, adult attachment, and sexual communication on sexual and marital satisfaction: a path analysis. J Sex Marital Ther. 2011; 37: 206223.

[43] Johnson SM, Brubacher LL. Emotionally focused couple therapy: empiricism and art. In: Sexton TL, Lebow J. (eds.) Handbook of family therapy. The science and practice of working with families and couples. Routledge, New York, NY, 2016; pp. 326348 .

(Désfalvi Judit, Budapest, Tömő u. 25-27., 1094 e-mail: desfalvijudit@gmail.com)

\section{„Verus amor nullum novit habere modum." (Propertius) (Az igazi szerelem nem ismer semmilyen mértéket.)}

A cikk a Creative Commons Attribution 4.0 International License (https://creativecommons.org/licenses/by/4.0/) feltételei szerint publikált Open Access közlemény, melynek szellemében a cikk bármilyen médiumban szabadon felhasználható, megosztható és újraközölhetö, feltéve, hogy az eredeti szerző és a közlés helye, illetve a CC License linkje és az esetlegesen végrehajtott módositások feltüntetésre kerülnek. (SID_1) 